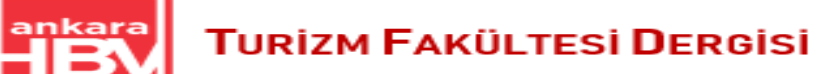

Dergi Ana Sayfası: https://dergipark.org.tr/tr/pub/ahbvtfd

ISSN: $2687-1912$

DOI: $10.34189 / \mathrm{tfd} .24 .02 .006$

\title{
İçerik Pazarlaması Kapsamında Hikayeleştirilmiş ve Geleneksel Video Tanıtımlarının Turistler Üzerindeki Rollerinin İncelenmesi: X ve Y Kuşaklarının Karşılaştırmalı Analizi \\ (Investigation of The Roles of Storyized and Traditional Video Promotions on Tourists Within Content Marketing: A Comparative Analysis of Generations X and Y)
}

\author{
*Büşra KAYA ${ }^{\mathrm{a}}$ \\ Olcay GÜDEK ${ }^{\mathrm{b}}$ \\ Azize HASSAN ${ }^{\mathrm{c}}$ \\ a Ankara Hacı Bayram Veli Üniversitesi, Lisansüstü Eğitim Enstitüsü, Ankara-Türkiye (busra.kaya650@hbv.edu.tr) https://orcid.org/0000- \\ 0002-6133-7518

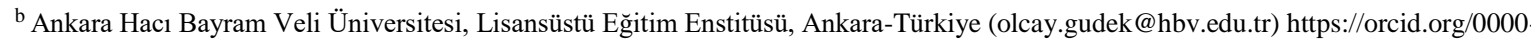 \\ 0002-5002-8306 \\ c Ankara Hacı Bayram Veli Üniversitesi, Turizm Fakültesi, Turizm İşletmeciliği Bölümü, Ankara-Türkiye (azize.hassan@hbv.edu.tr) \\ https://orcid.org/0000-0003-2509-1415
}

MAKALE GEÇMIŞí

Gönderim Tarihi:

03.07.2021

\section{Kabul Tarihi:}

23.10.2021

\begin{tabular}{l}
\hline Anahtar Kelimeler: \\
\hline İçerik Pazarlaması \\
Hikâyeleştirme \\
Turist \\
X kuşak \\
Y kuşak \\
$\underline{\text { Keywords: }}$ \\
\hline
\end{tabular}

Content Marketing

Storytelling

Tourist

X Generation

Y Generation

Makalenin Türü: Araştırma Makalesi

*Sorumlu Yazar: Büşra KAYA

E posta: busra.kaya650@hbv.edu.tr

\section{ÖZ}

\begin{abstract}
$\mathrm{Bu}$ çalışma ile içerik pazarlaması bağlamında hikâyeleştirme kullanımının turistler üzerindeki rolünü incelemek ve $\mathrm{X}$ ile $\mathrm{Y}$ kuşağı arasında karşıllaştırma yapmak amaçlanmıştır. Özellikle hikâyeleşmenin, dijitalleşen dünyada pazarlama açısından kullanımı giderek önemli hale gelmiştir. Söz konusu çalışma ile kuşaklar arasında geleneksel ya da hikâyeleştirilmiş tanıtımlar açısından farklılıklar gözlemlenmez ise hikâyeleştirmenin herkes için en etkili yöntem olduğu sonucuna ulaşılması amaçlanmaktadır. $\mathrm{Bu}$ durum, çalışmanın önemini vurgulamaktadır. Bu çalışma nitel araştırma yöntemlerinden fenomenoloji desenine dayanarak hazırlanmıştır. Veriler, 11 Y kuşağı ve $10 \mathrm{X}$ kuşağı olmak üzere 21 potansiyel turistten, yarı yapılandırılmış soru formu aracılığı ile toplanmıştır. Çalışmada içerik analizi yöntemi kullanılmıştır. Çalışmanın bulgularına göre; hikâyeleştirilmiş içerik videosunun, geleneksel tanıtım videosundan daha çok seyahat niyeti yarattı̆̆ 1 ve kuşaklararası farklılığa yol açmadığı tespit edilmiştir.
\end{abstract}

\section{ABSTRACT}

\begin{abstract}
The aim of this study is to examine the role of storytelling use on tourists in the context of content marketing and to make a comparison between generations $\mathrm{X}$ and $\mathrm{Y}$. The use of storytelling for marketing has become increasingly important, especially in the digitalizing world. With this study, it will be concluded that storytelling is the most effective method for everyone, especially if there are no differences between generations in terms of traditional or narrated presentations. This situation highlights the importance of the study. This study was prepared based on phenomenology pattern, one of the qualitative research methods. Data were collected from 21 potential tourists, 11 Generation $\mathrm{Y}$ and 10 Generation $\mathrm{X}$, via a semi-structured questionnaire. Content analysis was used in the study. According to the findings of the study; It has been determined that the narrated content video creates more travel intent than the traditional promotional video and does not cause intergenerational differences.
\end{abstract}

Makalenin Künyesi: Kaya, B., Güdek, O. \& Hassan, A. (2021). İçerik Pazarlaması Kapsamında Hikayeleștirilmiş ve Geleneksel Video Tanıtımlarının Turistler Üzerindeki Rollerinin Incelenmesi: X ve Y Kuşaklarının Karşılaştırmalı Analizi. AHBVÜ Turizm Fakültesi Dergisi, 24 (2), 284-309. 


\section{GIRIŞ}

Duyguların dâhil edildiği hikâyeleştirilmiş içerikler, özellikle postmodern tüketici profiline hitap etmekte ve deneyimi desteklemektedir. Postmodernizm sonrası deneyim yaratma, tüketiciyi üretici konumuna getirme ve etkileşim oldukça önemli bir hal almıştır (Kotler vd., 2020). Bu nedenle, turizm söz konusu olduğunda zenginleştirilmiş içerikler kullanmak gerekmektedir. Hikâyeleştirmeyle de turistlerde unutulmaz deneyimler yaratmak, sürece dâhil etmek ve etkileşim kurmak olasıdır (Kaya, 2020). Bu nedenle içerik pazarlaması bağlamında kullanılacak hikâyeleştirmenin, turist davranışlarını istenilen doğrultuda değiştirilebileceği düşünülmektedir. Dolayısıyla NAIDAS (Need: İhtiyaç, Attention: Dikkat, Interest: İlgi, Desire: Arzu, Action: Eylem, Satisfaction: Eylem) modelinde anlatıldı̆̆ı üzere; hizmet, mal ya da marka konumlandırmada, istenilen doğrultuda motive edilen tüketici, başlangıçta ihtiyaçlarının farkına varmaktadır. İkinci olarak hizmet, mal ya da marka tüketicinin dikkatini çekmektedir. Odaklanmış tüketicide arzulama arttıkça, ürünü/hizmeti arzulamaya başlamakta ve karşılı̆̆ında satın alma eylemini gerçekleştirmektedir. Son adımda ise müşteri memnuniyeti devreye girmekte ve bu süreçte tüketicinin zihninde istenilen marka imajı oluşturulmaktadır (Krom ve Güzel, 2016). Özetle NAIDAS modeli ile hikâyeleştirilmiş içeriklerin tüketici davranışı üzerindeki rolünü anlamlandırmak mümkün olabilecektir.

$\mathrm{Bu}$ çalışma ile içerik pazarlaması bağlamında hikâyeleştirme kullanımının turistler üzerindeki rolünü incelemek ve $\mathrm{X}$ ile $\mathrm{Y}$ kuşağı arasında karşılaştırma yapmak amaçlanmıştır. Hikâyeleştirmenin, özellikle dijitalleşen dünyada pazarlama açısından kullanımı giderek önemli hale gelmiştir. Yapılan çalışma ile kuşaklar arasında geleneksel ya da hikâyeleştirilmiş tanıtımlar açısından farklılıklar gözlemlenmez ise hikâyeleştirmenin herkes için en etkili yöntem olduğu sonucuna ulaşılacaktır. Bu durum da, çalışmanın önemini vurgulamaktadır.

Çalışmanın amaç ve önemine yönelik olarak geliştirilen araştırma soruları aşağıda yer aldığı gibidir:

- İçerik pazarlaması bağlamında hikâyeleştirme kullanımı, geleneksel pazarlamayla karşılaştırıldığında turistler üzerinde nasıl rol oynamaktadır?

- Hikâyeleştirilmiş içerikler X ve Y kuşakları üzerinde farklı bir çıktı mı sunmaktadır?

- Hikâyeleştirilmiş içerikler, geleneksel pazarlama araçlarına kıyasla daha fazla seyahat niyeti yaratır $\mathrm{m}$ ? 


\section{KAVRAMSAL ÇERÇEVE}

\section{1. İçerik Pazarlaması}

Günümüz tüketici veya müşterilerinin ürünler ile ilgili bilgi düzeylerindeki artış sebebiyle istekleri ve arzularının sürekli değiştiği gözlemlenmektedir. Tüketici veya müşterilerin sürekli değişen istek ve arzuları, üretilen mal ve hizmetleri satışa sunarken doyurucu düzeyde olmasını sağlamaktadır. Bu bağlamda pazarlama stratejilerinden biri olan içerik pazarlaması anlayışı önemini ortaya koymaktadır. İçerik pazarlamasıyla, tüketicinin veya müşterinin en uygun nicelik ve nitelik özelliklere sahip ürünü seçenekler arasından belirlemesi ve en üst düzey müşteri tatminini yaşaması amaçlanmaktadır. Öyle ki içerik pazarlaması, tüketici veya müşterinin zihinsel bir bilgi kirliğine neden olup seçenekler arasında çaresizlik yaşamadan ve satın alma hususunda kendisini baskı altında hissetmeden ihtiyacına yönelik olan uygun ürüne yaklaşımını ve satın almasına olanak tanımaktadır (Benli ve Karaosmanoğlu, 2017: 28). İçerik, bir tür yazılı, görsel veya işitsel formatta sunulan mesajların, fikirlerin ve bilgilerin derlemesidir (Diachuk, Britchenko ve Bezpartochnyi, 2019: 120). İçerik pazarlaması ise potansiyel müşteriyle birlikte hedef müşteri kitlesine odaklanan ilginç ve benzersiz içerikler oluşturarak, müşterilerinin dikkatini çekme, harekete geçirme ve içeriklerin yayınlama ile dağıtımını kapsayan pazarlama süreci olarak tanımlanmaktadır (Rahim ve Clemens, 2012: 897). Bir başka tanımlama ile içerik pazarlaması, ilgili ve değerli olan içerikler üreterek, başta dijital olmak üzere çeşitli kanallar aracılığıyla hedef kitlenin ilgisini çekme ve satışlar gerçekleştirme amacıyla yapılan pazarlama faaliyetleridir (Goldstein, 2013: 27). Kısaca içerik pazarlaması, ilgilenen veya ilgilenecekler için düzenli olarak değerli içeriklerin paylaşılması sanatı ve bilimi olarak tanımlanabilir (Harad, 2013: 18).

İçerik pazarlamasının amacına ulaşması ile başarı olması, içeriğin değerli olmasına bağlıdır. Değerli olan içerik, müşteriler için faydalı, eğitici ve ilham veren şekilde olması gerekmektedir (Jefferson ve Tanton, 2015: 23). Öyle ki müşteriler için içerikler oluşturulurken değerli, amacına uygun ve ilgi uyandırıcı bir hikâye olmasını zorunlu kılmaktadır (Pulizzi, 2012: 116). Nitekim hedef kitlesi olan müşterilere ulaşmak isteyenler, yaratıcı hikâye içerikleri oluşturmaktadır (Papadopoulos ve Shah, 2013: 122). Dolayısıyla içerik pazarlaması, hikâye anlatımıyla ilişsilendirilebilmektedir. Çünkü içerik pazarlamasının temel amacının ürün temelli mesajları müşterileri olan hedef kitleye aktarmaktan çok, bir hikâyesini anlatmak olduğu belirtilmektedir. Ancak içerik pazarlamasında iyi bir hikâye 
anlatımı yeterli olmaz, bu hikâyelerin hedef kitlenin duymak istediği hatta bunlara ihtiyacı olduğu hissini uyandırması gerekliliği her zaman göz önünde bulundurulmasını da gerektirir. $\mathrm{Bu}$ şekilde yaratılan etkili bir içerikle sadece mevcut değil, aynı zamanda potansiyel müşterilere de daha kolay ulaşılabileceği olanağı unutulmamalıdır (Penpeçe, 2013: 44).

\subsection{Hikâyeleştirme}

Hikâyenin tanımı Türk Dil Kurumu (2021) tarafından, “Bir olayın sözlü veya yazllı olarak anlatılması; aslı olmayan söz, olay; gerçek veya tasarlanmış olayları anlatan düz yazı türü, öykü” olarak verilmektedir. Boje'nin tanımına göre (1991: 111) hikâyeler; “Yaşanmış ya da yaşanacak deneyimi yorumlayan iki ya da daha fazla kişiyi içeren sözlü ya da yazılı performans" olarak görülmektedir. Kurgusal ya da gerçek olayların sesler, kelimeler ve fotoğraflar aracılığıyla aktarılması da hikâyeleştirmenin bir başka tanımıdır (Akgün vd., 2015). Hikâyeleştirme; deneyim ekonomisi, ağızdan ağıza pazarlama, değer yaratma, imaj oluşturma, örgüt içi iletişim gibi postmodernizm ile birlikte önem kazanan konularda turizm işletmeleri ve destinasyonlar için oldukça önemli bir araç haline gelmiştir (Boje, 1991; Kotler, Kartajaya ve Setiawan, 2010). İnsanlar deneyimlerini hikâyeleştirerek diğer insanlar ile paylaşma isteği duymaktadır (Kaya, 2020). Bu bağlamda, hikâyeleştirmenin, geçmişten gelen en eski ve etkili iletişim araçlarından biri olduğu görülmektedir (Uygur, Demirer ve Hatırnaz, 2017). İnsanlar, dünya görüşlerini ve kim olduklarını anlatırken, hikâyeleştirme ile herkese ulaşabilir ve iletişim kurabilir (Ross, 1992: 27). Buna dayanarak Pera (2017), hikâyeleştirmenin toplumsal temele dayanan deneyimler ortaya koyduğunu ve sosyalleşme yaratan kolektif bir süreç olduğunu vurgulamaktadır.

Hikâyeleştirme, insanlık var olduğundan beri kullanılmıştır. İlk insanlar mağara duvarlarına resimler çizerek hikâyelerini anlatırken, yazının keşfiyle hikâyeler kağıtlarda yer almıştır. Günümüzde ise, teknolojinin göz ardı edilemez gelişimiyle dijital platformlarda, yazılı ve sözlü olarak kullanılmaktadır (Turgut ve Kışla, 2015). Hikâyeleştirmenin, interaktif aktivitelerde ve internet günlüklerinde (bloglar ve vloglar) kullanılmaya başlanması ile yeni bir dönem doğmuştur (Mathews ve Wacker, 2009: 200). Öyle ki; kurumsal dergiler, haber bültenleri, blog gönderileri, videolar, web seminerleri, dijital ses dosyaları ve medya siteleri dahil olmak üzere birçok biçimde içerik pazarlaması görülmekte ve bu içerik pazarlama biçimlerinin tamamında bir şekilde hikâyeleştirme kullanmaktadır (Pulizzi, 2012). Bu görüşü Kee ve Yazdanifard (2015), hikâye anlatımının içerik pazarlamasının temeli olduğunu belirten 
ifadeleri ile desteklemektedirler. Ayrıca içerik pazarlama uygulama yolları olarak; yerelleştirme, kişiselleştirme, duygular, yaklaşımın çeşitlendirilmesi, birlikte oluşturma ve güven, etik ve dürüstlük unsurlarını da vermektedirler. Bu bağlamda, hikâyeleştirmenin içerik pazarlamasını uygulamak için en gerekli araç olduğu yadsınamaz bir gerçek olduğu söylenebilir.

\subsection{Kuşağı}

Bebek patlaması kuşağından sonra, 1965 yılı ile 1980 yılı arasında doğan insanların oluşturdukları kuşak, X kuşağı olarak isimlendirilmektedir (James vd., 2007; Mlodzik ve Meuse, 2012). İlk kez Coupland tarafindan 1989 yılında bu kuşak “ $X$ kuşağl” olarak anılmıştır (1989: 83). Otoriteye saygılı ve iş motivasyonları oldukça yüksektir (Mengi, 2009). $\mathrm{Bu}$ kuşağın üyeleri iş odaklı olmalarının yanı sıra özel yaşam ile iş yaşantısının dengesini önemserler ve bu konuda diğerlerinden saygı görmek isterler (Toruntay, 2011: 74). X kuşağ1 bireyleri; saygın bir statüye sahip olmayı, yüksek gelir elde etmeyi ve yüksek oranda sosyalleşme eğilimindedirler (Fox, 2011; Reilly, 2012). X kuşağında olan bireylerin satın alma davranışları ve ilişkili olarak pazarlama yaklaşımlarının ne olması gerektiği aşağıdaki gibidir (Pazarlamasyon, 2017):

- İnternetten alışveriş konusunda güvensiz ve uzaktırlar.

- Gerektiğinde tüketimi durduran tasarruf yönetimine sahip olup, Y ve Z kuşakları gibi duygusal ihtiyaç ile tüketim tercih etmemektedir. Daha çok fizyolojik ihtiyaçları önemsediği gözlemlenmiştir.

- Günümüzde geliri yükselen ve boş zamanı artan kesim bu kuşakta yer almaktadır. O nedenle yüksek bütçeli çoğu iş bu kesime hitap etmelidir.

- Sadakat duyguları gelişmiş olduğundan marka bağımlılıkları çok yüksektir. Postmodernizmde de istenen duygu bu olduğu için sadık müşteri yaratma ve elde tutma için bu kuşağa hitap oldukça önemlidir.

- Pazarlamacılar, bu kuşağa yönelik iletişimin kesilmemesi gerektiğini vurgulamaktadır.

- Aynı zamanda bu kuşaktaki kişiler ebeveyn kimlikleri nedeniyle Y, Z ve alfa kuşakları ile yakından ilgililerdir. Bu nedenle, gelenekselin yanı sıra dijital gelişmeleri de takip etmeleri gerekmektedir. Marka ve işletmeler X kuşağına ve henüz alım gücü olmayan $Z$ ve alfa kuşaklarına hitap etmek istiyorlarsa bütüncül kanal (omnichannel) yaklaşımı benimsemeli ve hem dijital hem de fiziksel ortamlarda bulunarak pazarlama 
faaliyetlerine bu şekilde devam etmelidir. Hüseyinoğlu (2017) göre Latince kökenli olup “tüm”, "her şey” ve "bütüncül” anlamlarına gelen omnichannel, elde edinilen deneyimlerin doğru bir şekilde kullanılması için offline ve online olan tüm kanallarda yönetilmesi anlamına gelmektedir.

X kuşağı bireylerinin, liderlik vasfı yüksektir ve pazarlama açısından ele alındığında köklü markalara öncelik verdiği görülmektedir (Kotler vd., 2021:37). Üstelik X kuşağı yaşam evresi açısından incelendiğinde ise koruyucu aşamadadır ve bu nedenle topluma katkı sağlama isteğiyle bu yönde davranışlar sergileyecektir. Sosyal sorumluluk, sürdürülebilirlik hedefleri ve topluma katkı sağlayacak değerler X kuşağının kararlarını etkilemektedir (Kotler vd., 2021:45).

\subsection{Y Kuşağı}

Kuşaklar arasında 1980 ile 1999 yıllarında doğanları kapsayan ve İngilizcede "Neden?” anlamına gelen “Why” kelimesinin okunuşu ile aynı olan " $Y$ ” harfi, söz konusu olan kuşağın isimlendirilmesi için uygun görülmüştür. Kuşağın isimlendirilmesinin temelinde bireylerin sorgulayıcı bir yapıda olması yatmaktadır (Cekada, 2012: 40). Öyle ki Y Kuşağı'nı diğer nesillerden ayıran en önemli özelliği tartışmacı olmasıdır. Birçok konuda keskin bir tavır takınan kuşak, her şeyin nedenini merak etmektedir. Y Kuşağ1 "Neden” sorusunu sormayı sevmekte ve otoriteye karşı boyun eğmeyen bir yapısı olduğunu göstermektedir. Ayrıca ilgisizliğe ve adaletsizliğe karşı mücadeleyi seven bir yapısı vardır (Türk, 2013: 68).

İnternet aracılığı ile uluslararası iletişimde bulunabilen Y kuşağı, ilk küresel müşteri grubunda yer almaktadır. Bu kuşak sosyal ağlar ile ürün tecrübelerini, bilgi ve fikirlerini paylaşıp karşılıklı iletişim halinde bulunurlar. Aynı zamanda kişisel ihtiyaç, istek ve seçimlerine özen göstermektelerdir. Y kuşağı tüketim odaklı olmakla birlikte karmaşık zevklere ve alışveriş eylemlerine sahip bir nesildir. Alışverişi sevme ve yüksek gelir düzeyine sahip olma özelliğinden dolayı perakende sektöründe bu etkinin büyük ölçüde devam edeceği öngörülmektedir (Okan ve Yalman, 2013: 140). Nitekim tüketici kitlesinin büyük bir bölümünü oluşturan, gelir seviyesi önceki kuşaklara nazaran yüksek olup güçlü harcamalar yapan, teknoloji ile iç içe olmalarından dolayı ürün veya marka ile ilgili bilgiye çok çabuk ulaşabilen, medya ve reklamların etkisi altında Y kuşağı çoğu pazarlamacı tarafından odak noktası olmaktadır. $\mathrm{Bu}$ yüzden firmaların pazarda aktif rol alabilmeleri veya olağan durumlarını koruyabilmeleri için tüketici kitlesinin önemli ve büyük bir bölümünü oluşturan 
Y kuşağının özelliklerini bilmeleri gerekmektedir. Bu özellikler doğrultusunda onlara uygun stratejiler geliştirmeleri, kendilerine başarı sağlayarak rakiplerinden öne çıkarabilecektir (Muskat ve diğerleri, 2013: 57).

Y kuşağı bireyleri sorgulamacı yapıdadır ve pazarlama açısından bakıldığında da köklü ve deneyim sunan markaları tercih ettiği görülmektedir (Kotler vd., 2021:37). Üstelik yaşam evreleri açısından incelendiğinde Y kuşağı evlilik ve doğum gibi geleneksel süreçleri geç yaşadığından koruyucu aşamada olduğu görülmektedir. Bu aşamada tıpkı X kuşağında olduğu gibi toplumsal fayda sağlayacak davranışlar sergileyecek ve davranışları da bu yönde olacaktır. Sosyal sorumluluk, sürdürülebilirlik hedefleri ve toplumsal değerler bu kuşak için de satın alma davranışını etkileyen özelliklerdir (Kotler vd., 2021: 45).

\section{YÖNTEM}

Araştırma nitel yönteme dayanmaktadır. Nitel yöntemlerden fenomenolojik desen benimsenmiştir. Fenomenolojik desen; bir olguya dair kişilerin deneyimi ve bu deneyime yükledikleri anlamları ortaya çıkarılmaya çalışmaktadır (Creswell, 2016). Nitel yöntem felsefi yaklaşımlarından biri olan sosyal yapı benimsenmiştir. Benimsenen felsefe, anlam arayışına ve sosyal etkileşim konuları temeline dayanmaktadır. Üstelik bu felsefe, kolektif bir süreçtir (Denzin ve Lincoln, 2005: 509). Araştırma süresince geçerlilik ve güvenilirlik bağlamında etik konular dikkate alınmıştır. Araştırmanın geçerliliğini sağlamak adına araştırmacılar ayrı ayrı analizi gerçekleştirmiş ve en sonunda birlikte son haline karar vermişlerdir. Ayrıca söz konusu analiz için bir uzman görüşü de gerçekleştirilmiştir. Bu bağlamda, çalışmanın analizi açısından geçerliliğinin sağlandığı söylenebilmektedir. Güvenilirlik bağlamında ise, kod anlamları değiştirilmemiş, süreç açıklıkla belirtilmiş ve tüm görüşme belgeleri kayıt altına alınmıştır.

\subsection{Evren ve Örneklem}

Araştırmanın evrenini sık seyahat eden turistler oluşturmaktadır. Nitel araştırmalar için evreni temsil eden örneklem, tekrara düşen yanıtlar alınana kadar görüşmeye devam ederek belirlenmektedir (Yıldırım ve Şimşek, 2008). Bu bağlamda, söz konusu çalışmada 21 potansiyel turist ile görüşülmüştür. 11 katılımcı X kuşağı, on katılımcı ise Y kuşağından olacak şekilde belirlenmiştir. Kolayda örnekleme yöntemi kullanılmıştır. Katılımcı turistler, Nemrut Dağı Sit Alanı'na yakın bölgeler olan; İç Anadolu ve Güneydoğu Anadolu Bölgesi'nde ikamet edenlerden seçilmiştir. 


\subsection{Veri Toplama Aracı}

Görüşme soruları NAIDAS modeli temel alınarak kişilerin davranış ve niyetlerinin incelenmesi amacıyla hazırlanmıştır. $\mathrm{Bu}$ model, iletişim sonucunda tüketicilerin davranışlarını nasıl değiştirebileceğini ortaya koyan AIDA modeline dayanmaktadır. AIDA modeline göre; tüketicinin ilgisi çekerek ürünle ilgilenmesi sağlanır, bu ilgiye dayanarak harekete geçmesi ve satın alması sağlanır. NAIDAS modeli ise bu modelin genişletişmiş halidir. Süreç benzer işlese de başlangıçta tüketicinin ihtiyaçları gözetilir ve sonuçta ise tüketicinin tatmini hedeflenmektedir (Aktuğlu, 2006). Bu nedenle, söz konusu çalışma için hazırlanan görüşme soruları bu model temel alınarak araştırmacılar tarafından hazırlanmıştır. Hazırlanan görüşme soruları, uzman görüşü alınarak son kullanım halini almıştır. Sorular yarı yapılandırılmış formda hazırlanmıştır. Kullanılan sorular aşağıdaki gibidir:

1. İzlediğiniz video sizde ne kadar seyahat etme ihtiyacı yarattı? Bu ihtiyacı nasıl tanımlarsinız?

2. İzlediğiniz videodan sonra bölge ile ilgili nasıl bir farkındalık yaşadınız?

3. İzlediğiniz videoda en çok ilginizi çeken nokta neydi? Neden ilginizi bu çekti?

4. İzlediğiniz videoda size o bölgeye seyahat etme isteği yaratan durum ya da unsur nedir? Neden bu durum sizde istek yarattı?

5. Bu videoda sizi seyahat planı için harekete geçiren durum/unsur nedir? Neden bu durum sizi harekete geçirdi?

6. İzlediğiniz video sonunda sizi bu seyahatte en çok tatmin edecek olduğunu düşündüğünü durum nedir? Neden bu durumun sizi tatmin edeceğini düşünüyorsunuz?

\subsection{Veri Toplama Süreci}

Yarı yapılandırılmış formdaki sorular, görüşme yolu ile belirlenen katılımcılara yöneltilerek veriler elde edilmiştir. Görüşmeler, yüz yüze ve salgın nedeni ile çevrimiçi yöntemler kullanılarak gerçekleştirilmiş olup, tüm görüşmeler kayıt altına alınmıştır. Görüşmeler 2021 yılının Şubat ve Mart aylarında gerçekleştirilmiştir.

Söz konusu çalışmada hikâyeleştirilmiş içeriklerin diğer içeriklere göre farklılıklarını ortaya koymak adına iki farklı tür tanıtım videosu izletilmiştir. Videolar içeriklerine göre seçilmiştir. Her iki videoda da "Nemrut Dağı Sit Alanı" tanıtımı yer almaktadır. Bu destinasyon seçiminin nedeni yeterince video içeriğine sahip olması ve hikayeleştirilmiş tanıtıma konu edilmiş olmasıdır. Tercih edilen ilk video, doğrudan bilgi aktarımı yapan geleneksel tanıtım 
aracıyken, ikinci tercih edilen videoda hikâyeleştirilmiş bir içerik söz konusudur. Tercih edilen videolar için uzman görüşü alınmıştır. Kullanılan videolar için, bilimsel etik çerçevesinde, içerik sahiplerinden kullanıma ilişkin izinler istenmiştir.

\subsection{Veri Analizi}

Seçilen videolar sırasıyla izletilmiştir. Öncelikle geleneksel tanıtım videosu izletilmiş ve sorular sorulmuş sonrasında ikinci video izletilmiş ve tekrar sorular sorulmuştur. Bunun nedeni, beklenen sonucu elde etmek adına hikâyeleştirilmiş içeriği önceden izletip sonuçları manipüle etmemektir. Görüşme sonucu 21 katılımcıdan elde edilen veriler, içerik analizi kullanılarak analiz edilmiştir. Verilen yanıtlar, temalar ve kodlar oluşturularak analiz edilmiştir. Bunun için seçici kodlama türü benimsenmiştir. Tüm kodlar ele alınıp ana temalar bu kodlara göre oluşturulmuştur.

\section{BULGULAR}

Yapılan araştırma sonucunda, toplanan veriler 1şığında öncelikle katılımcıların betimsel özellikleri aşağıda yer alan Tablo 1 üzerinde gösterilmiştir.

Katılımcılar, 26 - 51 yaş aralığında ve çeşitli meslek gruplarındandır. Katılımcıların 14'ünün medeni durumu bekârken, 7'si evlidir. 11 katılımcı erkek, 10 ise kadındır. Görüşme süreleri en az 11 dakika ve en fazla 27 dakika sürmüştür.

Tablo 1. Kat1lımciların betimsel analizi

\begin{tabular}{|c|c|c|c|c|c|c|}
\hline & Katılımeı & Meslek & $\begin{array}{l}\text { Medeni } \\
\text { Durum }\end{array}$ & Yaş & Cinsiyet & $\begin{array}{l}\text { Görüşme } \\
\text { Süreleri }\end{array}$ \\
\hline & K1 & Araştırma Görevlisi & Bekar & 29 & Erkek & 23 Dakika \\
\hline & $\mathrm{K} 2$ & $\begin{array}{l}\text { Müşteri } \\
\text { Sorumlusu }\end{array}$ & Evli & 28 & Kadın & 17 Dakika \\
\hline & K3 & $\begin{array}{l}\text { Rezervasyon } \\
\text { Sorumlusu }\end{array}$ & Evli & 29 & Kadın & 26 Dakika \\
\hline & K4 & Çalışmıyor & Bekar & 26 & Erkek & 20 Dakika \\
\hline 5 & K5 & Öğrenci & Bekar & 29 & Erkek & 19 Dakika \\
\hline so & K6 & Bilişim & Bekar & 29 & Kadin & 15 Dakika \\
\hline$\approx$ & K7 & Turizm & Bekar & 26 & Kadin & 18 Dakika \\
\hline$\lambda$ & K8 & Öğrenci & Bekar & 27 & Erkek & 22 Dakika \\
\hline & K9 & Turizm & Bekar & 28 & Erkek & 27 Dakika \\
\hline & K10 & Öğretim Görevlisi & Bekar & 26 & Kadın & 16 Dakika \\
\hline & K11 & Turizm & Bekar & 28 & Kadın & 19 Dakika \\
\hline & K12 & Restoran & Evli & 43 & Erkek & 14 Dakika \\
\hline & K13 & Emekli & Evli & 51 & Erkek & 11 Dakika \\
\hline$x_{1}$ & K14 & Muhasebe & Evli & 43 & Kadın & 15 Dakika \\
\hline & K15 & Turizm & Bekar & 42 & Kadın & 17 Dakika \\
\hline & K16 & Pazarlama & Evli & 45 & Erkek & 27 Dakika \\
\hline & K17 & Tekstil & Bekar & 48 & Kadın & 23 Dakika \\
\hline
\end{tabular}




$\begin{array}{llllll}\text { K18 } & \text { Tekstil } & \text { Bekar } & 42 & \text { Erkek } & \text { 13 Dakika } \\ \text { K19 } & \text { Tekstil } & \text { Bekar } & 44 & \text { Erkek } & \text { 20 Dakika } \\ \text { K20 } & \text { Yönetici } & \text { Evli } & 51 & \text { Erkek } & \text { 18 Dakika } \\ \text { K21 } & \text { Tekstil } & \text { Bekar } & 43 & \text { Kadın } & \text { 20Dakika }\end{array}$

Araştırmanın ilk sorusu olan "İzlediğiniz video sizde ne kadar seyahat etme ihtiyact yarattı? Bu ihtiyacı nasıl tanımlarsınız?" sorusu, katılımc1lara hem geleneksel tanıtım videosu hem de hikâyeleştirilmiş içerik videosu izletilerek yöneltilmiştir. Soruya ilişkin yanıtlardan elde edilen temalar ve kodlamalar aşağıda yer alan Tablo 2 üzerinde incelenmiştir. Hem X hem de Y kuşağı için iki tür video arasında gözlemlenen temel fark, geleneksel tanıtım videosunda olumsuz görüşler yarattığı olmuştur. Buna ek olarak, her iki kuşakta da hikâyeleştirilmiş içerik videosu sevdikleriyle birlikte deneyimleyeceği bir seyahat etme ihtiyacı yaratmıştır. Kuşaklararası bazı farklılıklar gözlemlense dahi hikâyeleştirilmiş içerik videosunda seyahat ihtiyacı bağlamında olumsuz görüş olmamakla beraber bu ihtiyacı sevdikleriyle paylaşma da gözlemlenmiştir. X kuşağı geleneksel tanıtım videosunu hem video kalitesi hem de duygusal açıdan olumsuz değerlendirirken, hikâyeleştirilmiş içerik videosunu olumlu yorumlamıştır.

Tablo 2. Turistlerin seyahat etme ihtiyac1

\begin{tabular}{|c|c|c|c|c|c|c|}
\hline \multicolumn{4}{|c|}{ X Kuşăğ } & \multicolumn{3}{|c|}{ Y Kuşağı } \\
\hline & Katılımcılar & Temalar & Kodlamalar & Katılımcılar & Temalar & Kodlamalar \\
\hline \multirow{8}{*}{ 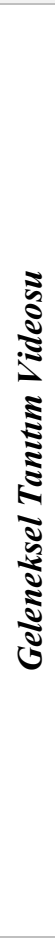 } & & Olumlu & & & Olumlu & \\
\hline & K14-K16 & Bilişsel & Bilgilendirme & $\begin{array}{l}\text { K2-K6-K7- } \\
\text { K8-K11 }\end{array}$ & Bilişsel & $\begin{array}{l}\text { Merak } \\
\text { uyandıran, } \\
\text { keşfetme arzusu } \\
\text { yaratan, bilgilen } \\
\text { dirici, değerli } \\
\text { bilgi, bilgi } \\
\text { edinme isteği, }\end{array}$ \\
\hline & $\begin{array}{l}\text { K15-K20- } \\
\text { K21 }\end{array}$ & Çekicilikler & $\begin{array}{l}\text { Kültür, mit, } \\
\text { hikâye }\end{array}$ & K4 & Deneyim & Deneyimleme \\
\hline & & Olumsuz & & K9 & Duygusal & Anlamlılık \\
\hline & K13 & Duygusal & $\begin{array}{l}\text { Heyecan } \\
\text { verici değil }\end{array}$ & K4-K5-K9 & Çekicilikler & $\begin{array}{l}\text { Tarih, kültür, } \\
\text { gün doğumu, } \\
\text { görülmeye } \\
\text { değer yap1, } \\
\text { UNESCO } \\
\text { Kültür Listesi }\end{array}$ \\
\hline & K12-K17 & Odaklanma & $\begin{array}{l}\text { Dikkat çekici } \\
\text { değil }\end{array}$ & & Olumsuz & \\
\hline & K18 & Konum & $\begin{array}{l}\text { Ulaşım } \\
\text { sıkıntısı }\end{array}$ & K10 & Odaklanma & İlgi çekici değil \\
\hline & K14 & $\begin{array}{l}\text { Video } \\
\text { Kalitesi }\end{array}$ & Amatör & & & \\
\hline$\Sigma$ & Katılımcılar & Temalar & Kodlamalar & Katılımcılar & Temalar & Kodlamalar \\
\hline
\end{tabular}




\begin{tabular}{|c|c|c|c|c|c|}
\hline $\begin{array}{l}\text { K12-K16- } \\
\text { K18 }\end{array}$ & Bilişsel & $\begin{array}{l}\text { İlgi çekici, } \\
\text { bilgi verici, } \\
\text { merak } \\
\text { uyandırıcı }\end{array}$ & K7-K8-K11 & Bilişsel & $\begin{array}{l}\text { Detayli bilgi, } \\
\text { sanatsal anlatim }\end{array}$ \\
\hline $\begin{array}{l}\text { K-13-K16- } \\
\text { K17-K20 }\end{array}$ & Duygusal & $\begin{array}{l}\text { Enfes, } \\
\text { mutluluk } \\
\text { verici, } \\
\text { romantizm, } \\
\text { heyecan verici }\end{array}$ & $\begin{array}{l}\text { K1-K3-K4- } \\
\text { K5-K8-K11 }\end{array}$ & Duygusal & $\begin{array}{l}\text { Etkileyici, } \\
\text { özgürlük hissi } \\
\text { veren, romantik } \\
\text { ambiyans, hisler }\end{array}$ \\
\hline $\begin{array}{l}\text { K19-K20- } \\
\text { K21 }\end{array}$ & Çekicilikler & $\begin{array}{l}\text { Gün doğumu, } \\
\text { otantik hava }\end{array}$ & $\begin{array}{l}\text { K2-K4-K5- } \\
\text { K6-K9 }\end{array}$ & Çekicilikler & $\begin{array}{l}\text { Gün doğumu, } \\
\text { kültürel miras }\end{array}$ \\
\hline K15 & Deneyim & $\begin{array}{l}\text { Deneyimleme } \\
\text { arzusu }\end{array}$ & $\begin{array}{l}\text { K4-K6-K8- } \\
\text { K11 }\end{array}$ & Deneyim & $\begin{array}{l}\text { Anı yaşama, } \\
\text { deneyimleme } \\
\text { arzusu }\end{array}$ \\
\hline K14-K15 & Paylaşım & $\begin{array}{l}\text { Sevdikleriyle } \\
\text { paylaşma } \\
\text { isteği, birlikte } \\
\text { deneyimleme } \\
\text { arzusu }\end{array}$ & K4-K5-K9 & Paylaşım & $\begin{array}{l}\text { Sevdikleri } \\
\text { biriyle paylaşma } \\
\text { isteği, birlikte } \\
\text { deneyimleme } \\
\text { arzusu }\end{array}$ \\
\hline K16 & $\begin{array}{l}\text { Video } \\
\text { Kalitesi }\end{array}$ & $\begin{array}{l}\text { Görüntü } \\
\text { kalitesi, iyi } \\
\text { hazırlanmış } \\
\text { kurgu }\end{array}$ & K5 & $\begin{array}{l}\text { Video } \\
\text { Kalitesi }\end{array}$ & Canlı renkler \\
\hline & & & K7-K10 & Değer & $\begin{array}{l}\text { Görmeye değer, } \\
\text { keşfedilmemiş } \\
\text { olması }\end{array}$ \\
\hline
\end{tabular}

“İlediğiniz videodan sonra bölge ile ilgili nasıl bir farkındalık yaşadınız?” sorusuna verilen yanıtlar ise aşağıda yer alan Tablo 3 üzerinde ele alınmıştır. Yanıtlardan elde edilen kodlamalar ve temalara göre, $\mathrm{X}$ kuşağı geleneksel tanıtım videosunu odaklanma ve değer bağlamında olumsuz değerlendirirken $\mathrm{Y}$ kuşağı yalnızca değer bağlamında olumsuz değerlendirmiştir. Her iki kuşak da hikâyeleştirilmiş içerik videosunu tamamen olumlu değerlendirmiştir. Geleneksel tanıtım videosunda bölgenin korunaksız, bakımsız olduğu izlenimi çizilmiştir. Bu nedenle hazırlanan video içeriklerinin görsel bağlamda da kaliteli olması gerekmektedir. Geleneksel tanıtım videosu, X kuşağı için duygusal anlamda hiçbir geri dönüş yaratmazken hikâyeleştirilmiş içeriklerde duygusal etkilerin olduğu gözlemlenmiştir. Buna ek olarak her iki kuşak için geleneksel tanıtım videoları deneyimleme arzusu yaratmazken, hikâyeleştirilmiş içerik videosu deneyime çağrı niteliğindedir. 
Tablo 3. Turistlerin Nemrut Dağı sit alanı'na yönelik farkındalıkları

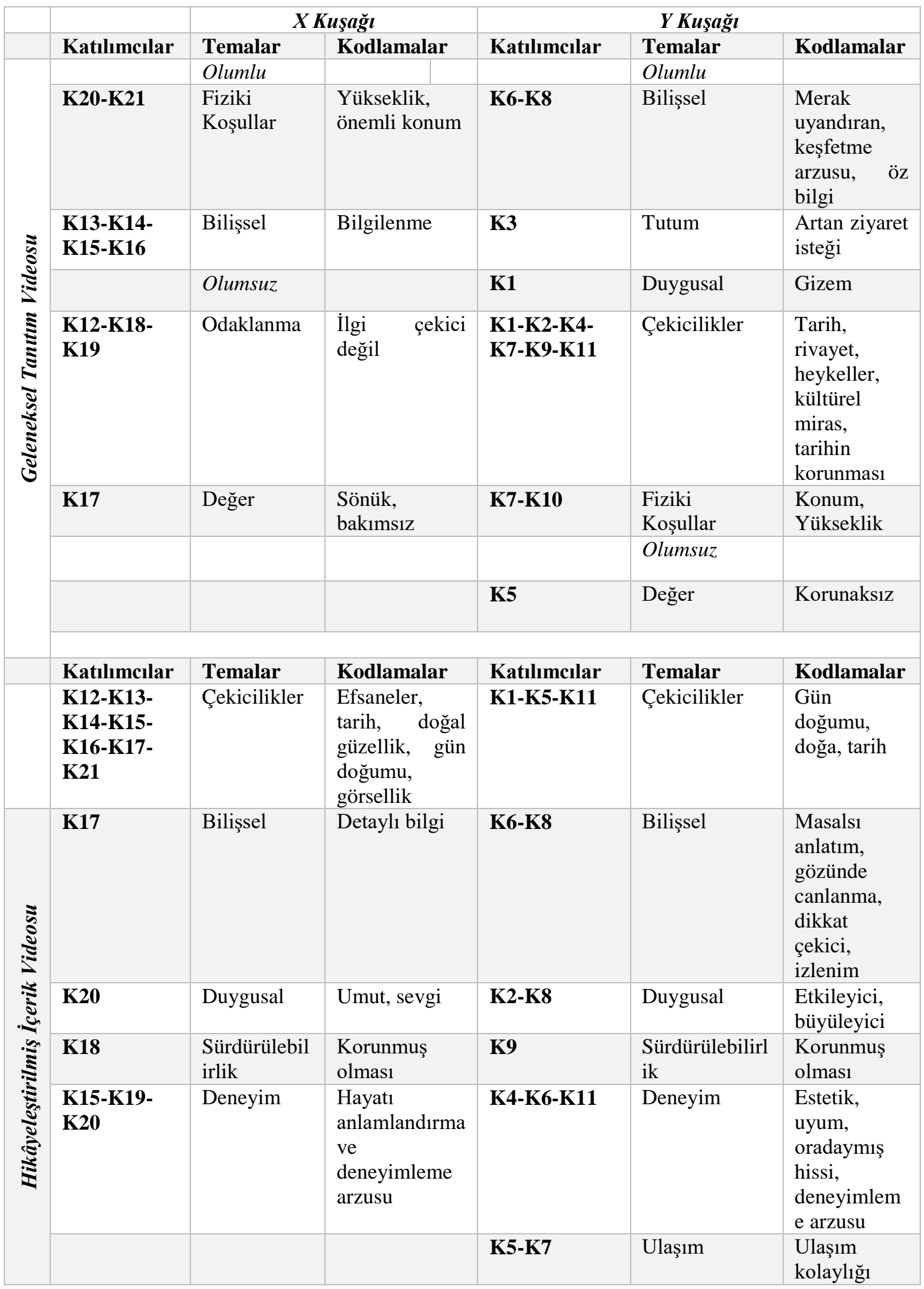


Araştırmanın üçüncü sorusu olan "İzlediğiniz videoda en çok ilginizi çeken nokta neydi? Neden ilginizi bu çekti?" sorusuna verilen yanıtlar aşağıda yer alan Tablo 4 üzerinde verilmiştir. Verilen yanıtlardan elde edilen kodlama ve temalara göre, en temel farklılık duygusallık üzerine olmuştur. Geleneksel tanıtım videosunda tek bir X kuşağı katılımcısının “gizemli" oluşu yönünde değerlendirmesi duygusal olarak ele alınmıştır. Bunun dışında duygu uyandırmadığı söylenebilmektedir. Bunun aksine, hikâyeleştirilmiş içerik videosunda sevgi, romantizm oldukça sık tekrar eden yanıtlar olmuştur. Video içeriğinde bu duyguların yoğun olarak işlenmesi, katılımcılarda sevdikleriyle paylaşma deneyimini de tetiklemiştir. Bunun yanı sıra, video kalitesi bağlamında iki video türü arasında farklılıklar vardır. Geleneksel tanıtım videosunda yalnızca akışın ve görüntü kalitesinin iyi olduğu belirtilirken, hikâyeleştirilmiş içerik videosunda renk ayarı, geniş açı, gerçek yolculuk hikâyesi gibi ifadeler de yer almaktadır. Y kuşağına göre ise hikayeleştirilmiş içerik duygusal ve deneyimsel açıdan en ilgi çekici görülürken, geleneksel tanıtım videosunda bu temaların ortaya çıkmadığı görülmüş̧ür. Diğer temalar bağlamında iki içerik arasında bir diğer farklılık ise geleneksel tanıtım videosunda anlatım ve ulaşım temalarının ortaya çıkmasıdır. Özetle iki tür arasındaki farklılığın anlatım ve ulaşım temaları yerine duygusal ve deneyimsel temaların ortaya çıkmasıdır. Hikayeleştirilmiş içeriklerde net bilgi veren anlatımlar ve ulaşıma dair notlar yerine duygu vurgusu yapılarak deneyimin ön plana çıkarıldığı görülmektedir.

Tablo 4. Turistlerin izledikleri videolarda bölgeye ilişkin ilgi çeken noktalar

\begin{tabular}{|c|c|c|c|c|c|c|}
\hline \multicolumn{4}{|c|}{ X Kuşağı } & \multicolumn{3}{|c|}{ Y Kuşağı } \\
\hline & Katılımcılar & Temalar & Kodlamalar & Katılımcılar & Temalar & Kodlamalar \\
\hline \multirow{5}{*}{ 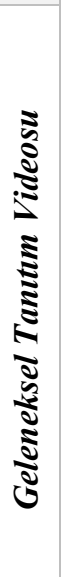 } & $\begin{array}{l}\text { K12-K15- } \\
\text { K16-K18 }\end{array}$ & Çekicilikler & $\begin{array}{l}\text { Gün doğumu, } \\
\text { tarihi, } \\
\text { heykeller }\end{array}$ & K7- K11 & Bilişsel & Bilgi \\
\hline & $\begin{array}{l}\text { K16-K17- } \\
\text { K18-K21 }\end{array}$ & $\begin{array}{l}\text { Fiziki } \\
\text { Koşullar }\end{array}$ & $\begin{array}{l}\text { Yükseklik, } \\
\text { konum }\end{array}$ & K8 & $\begin{array}{l}\text { Video } \\
\text { Kalitesi }\end{array}$ & Video akış1 \\
\hline & K13 & Duygusal & Gizem & K6-K7 & Anlatım & $\begin{array}{l}\text { Etkileyici } \\
\text { anlatım, samimi } \\
\text { anlatım }\end{array}$ \\
\hline & K14 & $\begin{array}{l}\text { Video } \\
\text { Kalitesi }\end{array}$ & $\begin{array}{l}\text { Görüntü } \\
\text { kalitesi }\end{array}$ & $\begin{array}{l}\text { K2-K4-K5- } \\
\text { K9-K10- } \\
\text { K11 }\end{array}$ & Çekicilikler & $\begin{array}{l}\text { Tarih, inanç, } \\
\text { heykellerin } \\
\text { korunması, gün } \\
\text { doğumu }\end{array}$ \\
\hline & & & & K1-K3 & $\begin{array}{l}\text { Fiziki } \\
\text { Koşullar }\end{array}$ & Yükseklik \\
\hline & Katılımcılar & Temalar & Kodlamalar & Katılımcılar & Temalar & Kodlamalar \\
\hline 氛: & $\begin{array}{l}\text { K12-K13- } \\
\text { K15-K16- } \\
\text { K17-K20 }\end{array}$ & Çekicilikler & $\begin{array}{l}\text { Gün doğumu, } \\
\text { rivayet }\end{array}$ & $\begin{array}{l}\text { K1-K2-K4- } \\
\text { K5-K6-K9- } \\
\text { K10 }\end{array}$ & Çekicilikler & $\begin{array}{l}\text { Gün doğumu, } \\
\text { rivayet, } \\
\text { ambiyans, } \\
\text { kültür, mimari }\end{array}$ \\
\hline
\end{tabular}




\begin{tabular}{|c|c|c|c|c|c|}
\hline $\begin{array}{l}\text { K17-K18- } \\
\text { K21 }\end{array}$ & Ulaşım & $\begin{array}{l}\text { Zorlu } \\
\text { yolculuk, } \\
\text { ulaşım zorluğu }\end{array}$ & K7 & Ulaşım & Kolay ulaşım \\
\hline K19 & Duygusal & Gizem & K4-K5 & Duygusal & $\begin{array}{l}\text { Gizem, } \\
\text { etkileyici, } \\
\text { romantizm, } \\
\text { sevgi }\end{array}$ \\
\hline K14 & $\begin{array}{l}\text { Video } \\
\text { Kalitesi }\end{array}$ & $\begin{array}{lr}\text { Renk } & \text { ayarı, } \\
\text { geniş } & \text { aç1, } \\
\text { görüntü } & \\
\text { kalitesi } & \end{array}$ & K8 & $\begin{array}{l}\text { Video } \\
\text { Kalitesi }\end{array}$ & $\begin{array}{l}\text { Video akışı, } \\
\text { gerçek yolculuk } \\
\text { hikâyesi }\end{array}$ \\
\hline K16 & $\begin{array}{l}\text { Fiziki } \\
\text { Koşullar }\end{array}$ & Konum & K11 & Deneyim & $\begin{array}{l}\text { Hazcilık, } \\
\text { deneyimleme } \\
\text { arzusu }\end{array}$ \\
\hline K15 & Paylaşım & $\begin{array}{l}\text { Sevdiği biriyle } \\
\text { paylaşma }\end{array}$ & $\begin{array}{l}\text { K3-K7- } \\
\text { K10-K11 }\end{array}$ & Bilişsel & $\begin{array}{l}\text { Detayli bilgi, } \\
\text { tarihi bilgi, ilgi } \\
\text { çekici }\end{array}$ \\
\hline
\end{tabular}

"İzlediğiniz videoda size o bölgeye seyahat etme isteği yaratan durum ya da unsur nedir? Neden bu durum sizde istek yarattı?" sorusuna verilen yanıtlar aşağıda yer alan Tablo 5 üzerinde incelenmiştir. Yanıtlara göre, X kuşağı katılımcıların yarısının seyahat etme niyetini geleneksel tanıtım videosunda olumsuz değerlendirdiği görülmektedir. Bunun aksine $\mathrm{Y}$ kuşağı geleneksel tanıtım videosunu tamamen anlamsız değerlendirmemiş ve hiç olumsuz geribildirimde bulunmamıştır. Hikâyeleştirilmiş içerik videosunda ise iki kuşak arasında neredeyse hiç farklılık gözlemlenmemiştir. Her iki kuşak da beş ortak temadan etkilenirken, farklı olarak X kuşağı bölgenin değerinden, Y kuşağı ise yapı ve yüksekliğinden etkilenmiştir.

Tablo 5. Turistlerde seyahat etme niyeti yaratan unsurlar

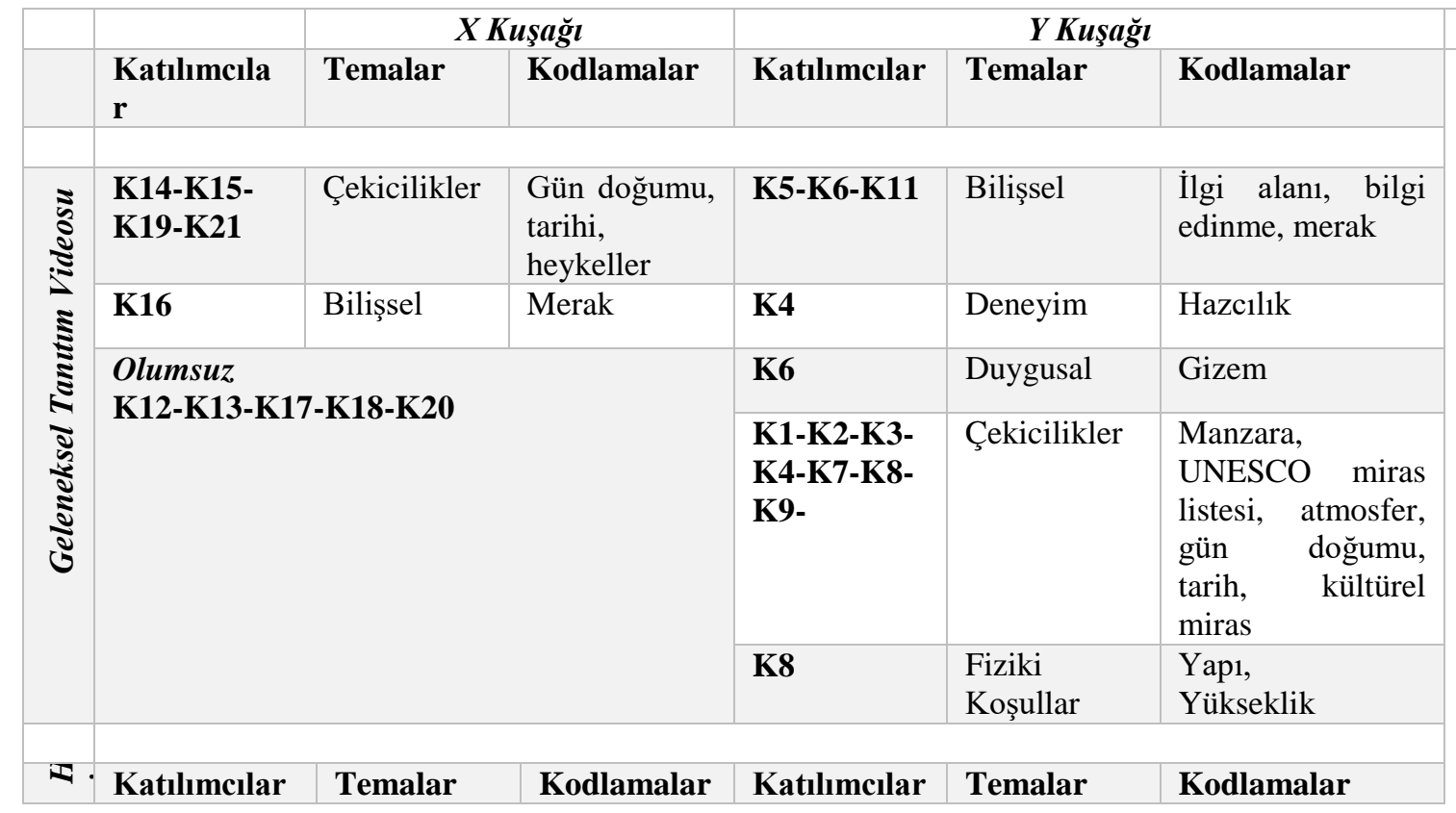




\begin{tabular}{|c|c|c|c|c|c|}
\hline $\begin{array}{l}\text { K12-K14- } \\
\text { K16 }\end{array}$ & Çekicilikler & $\begin{array}{l}\text { Tarih, doğa, } \\
\text { heykeller, } \\
\text { gün doğumu, } \\
\text { manzara }\end{array}$ & $\begin{array}{l}\text { K3-K5-K8- } \\
\text { K9-K10 }\end{array}$ & Çekicilikler & $\begin{array}{l}\text { Doğa, manzara, } \\
\text { gün doğumu, } \\
\text { kültür, tarih }\end{array}$ \\
\hline $\begin{array}{l}\text { K13-K14- } \\
\text { K17-K19- } \\
\text { K21 }\end{array}$ & Duygusal & $\begin{array}{l}\text { Samimi, } \\
\text { duyguların } \\
\text { dahil } \\
\text { edildiği, } \\
\text { gizem, } \\
\text { hayranlık }\end{array}$ & K1-K4-K5 & Duygusal & $\begin{array}{l}\text { Özgürlük hissi, } \\
\text { gizem, romantizm }\end{array}$ \\
\hline K17 & Bilişsel & $\begin{array}{l}\text { Dikkat } \\
\text { çekici, net }\end{array}$ & K6-K11 & Bilişsel & $\begin{array}{l}\text { Keşfetme isteği, } \\
\text { öğrenme }\end{array}$ \\
\hline $\begin{array}{l}\text { K15-K16- } \\
\text { K20 }\end{array}$ & Paylaşım & $\begin{array}{l}\text { Sevdikleriyl } \\
\text { e paylaşma }\end{array}$ & K2 & Paylaşım & $\begin{array}{l}\text { Sevdikleriyle } \\
\text { paylaşma }\end{array}$ \\
\hline K15-K20 & Deneyim & $\begin{array}{l}\text { Anlam } \\
\text { kazanma, } \\
\text { deneyimlem } \\
\text { e arzusu }\end{array}$ & $\begin{array}{l}\text { K1-K2-K3- } \\
\text { K7-K11 }\end{array}$ & Deneyim & $\begin{array}{l}\text { Deneyimleme } \\
\text { arzusu, güzel } \\
\text { anılar yaratma } \\
\text { isteği, hazcilı, } \\
\text { estetik, iyi vakit } \\
\text { geçirme }\end{array}$ \\
\hline K18 & Değer & $\begin{array}{l}\text { Değerli } \\
\text { bölge }\end{array}$ & K9 & $\begin{array}{l}\text { Fiziki } \\
\text { Koşullar }\end{array}$ & Yükseklik, yapı \\
\hline
\end{tabular}

Araştırmanın beşinci sorusu olan "Bu videoda sizi seyahat planı için harekete geçiren durum/unsur nedir? Neden bu durum sizi harekete geçirdi? " sorusuna verilen yanıtlar aşağıda yer alan Tablo 6 üzerinde verilmiştir. Verilen yanıtlardan elde edilen kodlama ve temalara göre, geleneksel tanıtım videolarında her iki kuşak için farklılıklar gözlemlenirken, hikâyeleştirilmiş içerik videosu için benzer yanıtlar verilmiştir. X kuşağı, seyahat niyeti ile benzer doğrultuda yanıtlar vermiş ve beş katılımcı harekete geçme konusunda olumsuz bir tutum sergilemiştir. Bununla birlikte, Y kuşağı geleneksel tanıtım videosunu daha bilişsel değerlendirirken, hikâyeleştirilmiş içerik vidosu duygusal olarak belirtilmiştir. Üstelik Y kuşağını harekete geçiren bir diğer farklı unsur ise video kalitesi olmuştur. Öyle ki renklerin canlılığı, geniş açı çekimler katılımcılarda yalnızca seyahat planı için harekete geçiren bir unsur değil aynı zamanda deneyimleme arzusu da yaratan bir unsur olarak görüşmüştür. K7 bu konudaki yorumunu şöyle belirtmiştir: "Video da tarihi bilgilerin daha detayll verilmesi ve 360 derece tüm dă̆ın görüntüsünün gösterilmesi, kültür turu yapma isteği uyandırdı”. 
Tablo 6. Turistleri seyahat planı için harekete geçiren unsurlar

\begin{tabular}{|c|c|c|c|c|c|c|}
\hline & \multirow[b]{2}{*}{$\begin{array}{l}\text { Katılımci } \\
\text { lar }\end{array}$} & \multicolumn{2}{|c|}{ X Kuşăğ } & \multicolumn{3}{|c|}{ Y Kuşağı } \\
\hline & & Temalar & Kodlamalar & $\begin{array}{l}\text { Katılımel } \\
\text { ar }\end{array}$ & Temalar & Kodlamalar \\
\hline \multirow{5}{*}{ 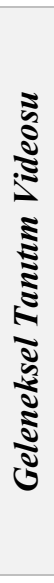 } & K14 & $\begin{array}{l}\text { Fiziki } \\
\text { Koşullar }\end{array}$ & Yükseklik & $\begin{array}{l}\text { K1-K5- } \\
\text { K6-K7- } \\
\text { K11 }\end{array}$ & Bilişsel & $\begin{array}{l}\text { Bilgi, merak, öğrenme } \\
\text { isteği, keşfetmek }\end{array}$ \\
\hline & K16-K21 & Bilişsel & $\begin{array}{l}\text { Bilgilenme, } \\
\text { merak }\end{array}$ & K4-K8-K9 & Deneyim & $\begin{array}{l}\text { Anlamlılik, } \\
\text { deneyimleme arzusu }\end{array}$ \\
\hline & $\begin{array}{l}\text { K14- } \\
\text { K15- } \\
\text { K16- } \\
\text { K19-K21 }\end{array}$ & Çekicilikler & $\begin{array}{l}\text { Atmosfer, miras, } \\
\text { heykeller, tarih }\end{array}$ & K9 & Değer & Değerli görme \\
\hline & \multirow{2}{*}{\multicolumn{3}{|c|}{$\begin{array}{l}\text { Olumsuz, } \\
\text { K12-K13-K17-K18-K20 }\end{array}$}} & $\begin{array}{l}\text { K2-K3- } \\
\text { K7-K8- } \\
\text { K9-K10 }\end{array}$ & Çekicilikler & $\begin{array}{l}\text { Tarih, UNESCO miras } \\
\text { listesi, gün doğumu, } \\
\text { kültür, heykeller, cazibe }\end{array}$ \\
\hline & & & & K4-K7-K8 & $\begin{array}{l}\text { Fiziki } \\
\text { Koşullar }\end{array}$ & $\begin{array}{l}\text { Konum, } \\
\text { Yükseklik }\end{array}$ \\
\hline \multirow{7}{*}{ 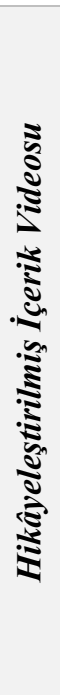 } & $\begin{array}{l}\text { Katılımcil } \\
\text { ar }\end{array}$ & Temalar & Kodlamalar & $\begin{array}{l}\text { Katılımcıl } \\
\text { ar }\end{array}$ & Temalar & Kodlamalar \\
\hline & K16-K19 & Duygusal & $\begin{array}{l}\text { Cezbedici, } \\
\text { heyecan verici }\end{array}$ & K8-K10 & Duygusal & Gizem \\
\hline & $\begin{array}{l}\text { K13-K14- } \\
\text { K16-K17- } \\
\text { K18-K20 }\end{array}$ & Çekicilikler & $\begin{array}{l}\text { Gün doğumu, } \\
\text { görsellik, } \\
\text { tarih, doğa }\end{array}$ & $\begin{array}{l}\text { K2-K3- } \\
\text { K5-K10- } \\
\text { K11 }\end{array}$ & Çekicilikler & Gün doğumu, tarih \\
\hline & $\begin{array}{l}\text { K12-K15- } \\
\text { K19-K21 }\end{array}$ & Deneyim & $\begin{array}{l}\text { Tarihe } \\
\text { tanıklık, } \\
\text { deneyimleme } \\
\text { arzusu }\end{array}$ & $\begin{array}{l}\text { K1-K3- } \\
\text { K4-K9- } \\
\text { K11 }\end{array}$ & Deneyim & Deneyimleme arzusu \\
\hline & K15 & Paylaşma & $\begin{array}{l}\text { Sevdikleriyle } \\
\text { paylaşma }\end{array}$ & K5-K9 & Paylaşma & Sevdikleriyle paylaşma \\
\hline & \multirow[t]{2}{*}{ K17 } & \multirow[t]{2}{*}{ Değer } & \multirow[t]{2}{*}{ Değerli bölge } & K6-K7 & $\begin{array}{l}\text { Video } \\
\text { Kalitesi }\end{array}$ & Geniş açı, anlatım \\
\hline & & & & K4-K5 & $\begin{array}{l}\text { Fiziki } \\
\text { Koşullar }\end{array}$ & Konum, yap1 \\
\hline
\end{tabular}

Araştırmanın altıncı ve son sorusu olan "İzlediğiniz video sonunda sizi bu seyahatte en çok tatmin edecek olduğunu düşündüğünü durum nedir? Neden bu durumun sizi tatmin edeceğini düşünüyorsunuz?" sorusuna verilen yanıtlar, aşağıda yer alan Tablo 7 üzerinde verilmiştir. Yanitlardan elde edilen kodlama ve temalara göre, deneyimin her iki video türü ve her iki kuşak için en önemli çıktı olduğu görülmektedir. Katılımcılar, seyahatlerini tatmin edici k1lacak şeyin, destinasyonlarda yaşanacak deneyimler olduğunu belirtmişlerdir. Öyle ki K17 "Tarihe yakından şahitlik etmek ve Misır piramitlerini gölgede bırakan o tahtı arkama alarak gün doğumu izlemek." yanıtı ile özellikle tarihe tanıklık etmenin vurgusunu yapmıştır. Ek olarak, bu yanıttan yola çıkarak video içeriğindeki güçlü söylemlerin, kişiler için akılda kalıcı 
ve ilgi uyandırıcı olduğu da söylenebilmektedir. Tatmin edici unsurlar bağlamında ortaya çıkan bir diğer farklılık ise sürdürülebilirliktir. X kuşağı, destinasyondaki kültürel mirasın korunmasını ve sürdürülebilir olmasını tatmin edici olarak değerlendirmiştir. Y kuşağı ise, farkındalık bağlamında sürdürülebilirliği önemsediğini belirtirken, tatmin edici bir unsur olarak değerlendirmemiştir.

Tablo 7. Turistlerin seyahatlerini tatmin edici k1lacak unsurlar

\begin{tabular}{|c|c|c|c|c|c|c|}
\hline \multirow{6}{*}{ 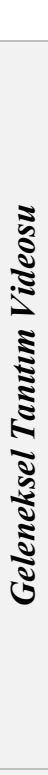 } & \multirow[b]{2}{*}{ Katılımcılar } & \multicolumn{2}{|c|}{ X Kuşă̆ı } & \multicolumn{3}{|c|}{ Y Kuşă̆ı } \\
\hline & & Temalar & Kodlamalar & Katılımcılar & Temalar & Kodlamalar \\
\hline & K17 & Deneyim & $\begin{array}{l}\text { Tarihe } \\
\text { tanıklık, yeni } \\
\text { bir yer } \\
\text { görmek, } \\
\text { deneyim }\end{array}$ & $\begin{array}{l}\text { K1-K2-K3- } \\
\text { K4-K10- } \\
\text { K11 }\end{array}$ & Deneyim & $\begin{array}{l}\text { Anı biriktirmek, geçmişe } \\
\text { tanıklık etmek, gizemi } \\
\text { koruyan bölgede bulunmak, } \\
\text { UNESCO miras listesinde } \\
\text { yer alan yere ziyaret, } \\
\text { hazcılık, deneyimleme }\end{array}$ \\
\hline & $\begin{array}{l}\text { K15-K16- } \\
\text { K18 }\end{array}$ & $\begin{array}{l}\text { Fiziki } \\
\text { Koşullar }\end{array}$ & Yükseklik & $\begin{array}{l}\text { K3-K6-K7- } \\
\text { K8-K11 }\end{array}$ & Bilişsel & $\begin{array}{l}\text { Zihinde canlandirma, hayal } \\
\text { edebilme, anlatım, bilgi } \\
\text { edinme }\end{array}$ \\
\hline & K12 & $\begin{array}{l}\text { Sürdürüleb } \\
\text { ilirlik }\end{array}$ & $\begin{array}{l}\text { Yapının } \\
\text { korunması }\end{array}$ & K3-K5- & Çekicilikler & Gün doğumu, tarih \\
\hline & $\begin{array}{l}\text { K12-K14- } \\
\text { K15-K17- } \\
\text { K19-K20- } \\
\text { K21 }\end{array}$ & $\begin{array}{l}\text { Çekicilikle } \\
\mathrm{r}\end{array}$ & $\begin{array}{l}\text { Gün } \\
\text { doğumu, } \\
\text { tarihi, } \\
\text { atmosfer, } \\
\text { heykeller }\end{array}$ & & & \\
\hline & Katılımcılar & Temalar & Kodlamalar & Katılımcılar & Temalar & Kodlamalar \\
\hline & $\begin{array}{l}\text { K12-K15- } \\
\text { K17-K18- } \\
\text { K20-K21 }\end{array}$ & Deneyim & $\begin{array}{l}\text { Deneyimlem } \\
\text { e arzusu, } \\
\text { tarihe } \\
\text { tanıklık, anı } \\
\text { yaratma, } \\
\text { anlamlılık }\end{array}$ & $\begin{array}{l}\text { K1-K2-K3- } \\
\text { K4-K5-K7- } \\
\text { K7-K9-K10 }\end{array}$ & Deneyim & $\begin{array}{l}\text { Değerleri } \quad \text { görmek, } \\
\text { deneyimleme } \\
\text { hazcılık }\end{array}$ \\
\hline$\frac{\pi}{3}$ & $\begin{array}{l}\text { K13-K14- } \\
\text { K19 }\end{array}$ & Duygusal & $\begin{array}{l}\text { Duygu yüklü } \\
\text { olmas1, } \\
\text { gizem }\end{array}$ & K1-K9 & Duygusal & $\begin{array}{l}\text { Özgürlük hissi, duygusal } \\
\text { yön, mutluluk }\end{array}$ \\
\hline 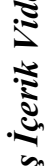 & $\begin{array}{l}\text { K14-K16- } \\
\text { K17-K18- } \\
\text { K19 }\end{array}$ & $\begin{array}{l}\text { Çekicilikle } \\
\mathrm{r}\end{array}$ & $\begin{array}{l}\text { Gün } \\
\text { doğumu, } \\
\text { tarih, } \\
\text { heykeller }\end{array}$ & $\begin{array}{l}\text { K6-K7-K8- } \\
\text { K9-K10 }\end{array}$ & Çekicilikler & $\begin{array}{l}\text { Tarih, atmosfer, gün } \\
\text { doğumu }\end{array}$ \\
\hline 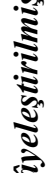 & K15-K19 & Paylaşma & $\begin{array}{l}\text { Sevdikleriyl } \\
\text { e beraber } \\
\text { deneyimlem } \\
\text { e isteği }\end{array}$ & K5-K9-K11 & Paylaşma & $\begin{array}{l}\text { Sevdikleriyle } \\
\text { deneyimleme isteği }\end{array}$ \\
\hline$\sqrt[3]{2}$ & K12 & Sürdürüleb & Heykellerin & K9 & Bilişsel & Hayal gücünde canlandırma \\
\hline & & ilirlik & korunmas1 & K4 & $\begin{array}{l}\text { Fiziki } \\
\text { Koşullar }\end{array}$ & Konum \\
\hline
\end{tabular}




\section{SONUÇ VE ÖNERILER}

$\mathrm{Bu}$ çalışma ile içerik pazarlaması bağlamında hikâyeleştirme kullanımının turistler üzerindeki rolünü incelemek ve X ile Y kuşağı arasında karşılaştırma yapmak amaçlanmıştır. Çalışmanın sonucunda amaca uygun olarak, hikâyeleştirilmiş içerik videosu ve geleneksel tanıtım videosu arasındaki farklar X ve Y kuşakları bağlamında belirlenmiştir.

Ortaya çıkan bulgular ışığında, kuşak ayrımı yapmaksızın herkesi etkileyecek bir tanıtım yapılmak isteniyor ise içerik pazarlaması bağlamında hikâyeleştirmenin mutlaka kullanılması gereken bir araç olduğu söylenebilir. Tüm sonuçlar incelendiğinde ise geleneksel tanıtım videosu söz konusu olduğunda $\mathrm{X}$ ve $\mathrm{Y}$ kuşakları arasında farklılıklar oldukça fazlayken, hikâyeleştirilmiş içerik vidosunda benzer çıktılar gözlemlenmiştir.

İhtiyaç aşamasında, özellikle hedef kitlesi X kuşağı olanların mutlaka duygu temeline dayanan içerikler üretmek zorunda oldukları ve her iki kuşak için de video kalitesinin oldukça önem taşıdığı ortaya çıkmıştır. Farkındalık bağlamında, geleneksel tanıtım videosunun destinasyonu daha değersiz yansıttığı görülürken özellikle ilgi çekmek ve niyet oluşturmak için farkındalık oldukça önemli bir adımken, destinasyonlar hakkında yanlış izlenim yaratmak da büyük bir hata olacaktır. Bu nedenle bu aşamada mutlaka destinasyon değerinin vurgulanması gerekmektedir. Ayrıca mutlaka deneyimi vurgulayacak, hikâyeleştirilmiş bir içerik de sunulmalıdır. Pazarlama 5.0 ile deneyim ve değerin mutlaka yaratılması gerektiği göz önüne serilmiştir (Kotler vd. 2021:36). Duygusallık, kişilerde sevdikleriyle paylaşma ve sevdikleriyle deneyimleme çıktılarını da tetiklediği için ilgi çekme aşamasında, mutlaka yer almalıdır. Duygusal bulaşıcılık ile paylaşımlar tetiklenmekte ve benzer duygudaki insanlar da birbirini etkilemektedir (Koçak Kurt, 2021). Bu nedenle hem deneyime katılmalarını sağlamak hem paylaşmalarını sağlamak hem de sevdikleriyle ziyaret etmelerini sağlamak büyük avantaj yaratabilecektir. Tanıtımı izleyen tek bir kişi ile birçok kişiye ulaşmanın kolay ve hızlı yolu hikâyeleştirilmiş içeriklerden geçmektedir. Seyahat etme niyetini, tüm katılımcılardan yalnızca ikisi geleneksel tanıtım video ile sağladığını belirtmiştir. Bunun nedeni ise farklı turist profillerinin söz konusu olmasıdır. Bilgi odaklı turist profillerinin beklentileri farklı olduğu için duygusal ve deneyim odaklı olan hikâyeleştirilmiş içerikler çekici olmamaktadır. Ancak katılımcıların çoğu bunun aksine hikâyeleştirilmiş içerik videosunu tercih etmiştir. Verilen yanıtlarda da özellikle X kuşağının geleneksel tanıtım 
videosunu seyahat niyeti bağlamında olumsuz değerlendirdiği görülmektedir. Seyahat planı için harekete geçme bağlamında ise geleneksel tanıtım videosu X kuşağının çoğu tarafından olumsuz değerlendirmiştir. Y kuşağı ise geleneksel tanıtım videosunu daha bilişsel değerlendirirken, hikâyeleştirilmiş içerik videosunu duygusal olarak tanımlamıştır. Son aşama olan tatmin edici unsurlarda ise kuşak ve video fark etmeksizin deneyim sonucuna ulaşılmıştır. Bunun yanı sıra X kuşağı sürdürülebilirliği bir tatmin unsuru olarak her iki video türünde de belirtmiştir.

Araştırma sorularına yönelik bulgular ışı̆̆ında verilebilecek özet yanıtlar ise şu şekilde derlenmiştir:

- İçerik pazarlaması bağlamında hikâyeleştirme kullanımı, geleneksel pazarlamayla karşılaştırıldı ğında turistler üzerinde nasıl rol oynamaktadır?

Geleneksel pazarlama X kuşağı tarafindan seyahat etme niyeti ve birçok boyutta olumsuz karşılanmıştır. Y kuşağı ise tamamen olumsuz değerlendirmese de hikâyeleştirilmiş içeriği tercih etmektedir. $\mathrm{Bu}$ bağlamda geleneksel, salt bilgiye dayanan eski tanıtım videoları günümüzde artık turistlerin ilgisini çekmemektedir. Üstelik deneyimleme ve hatta sevdikleriyle deneyimleme anlamında hikâyeleştirilmiş içerik pazarlaması oldukça etkili olarak görülmektedir. Elde edilen bu bulgular Akbayır'ın (2016) çalışması ile örtüşmektedir. Akbayır (2016) çalışmasında marka iletişimi bağlamında hikayeleştirmenin deneyim sunma açısından etkili olduğuna yer vermektedir.

- Hikâyeleştirilmiş içerikler X ve Y kuşakları üzerinde farklı bir çıktı sunmakta mıdır?

Genel anlamda aynı çıktıları sunsa da bazı noktalarda farklılaşmaktadır. Örneğin X kuşağı daha duygusal değerlendirirken (ki bunu sadakati en yüksek olan kuşak olması ile bağdaştırmak mümkün)Y kuşağı hem bilişsel hem de duygusal değerlendirmektedir. Y kuşağının aslında bütüncül bakış açısı da bu kuşağa ait özelliklerden biridir. Bu kuşak yalnızca bilgi ya da yalnızca duygusal tatmin beklentisinde değil, ödediği paranın tam karşılığını almak isteyen bir kuşaktır (Kotler vd. 2021:39). Bu nedenle bu durum kabul edilebilirdir. Bunun yanı sıra bir farklılık da video kalitesidir. Y kuşağı video kalitesini daha çok önemsemektedir. Ayrıca X kuşağı sürdürülebilirliği daha çok önemserken ve tatmin edici bulurken, Y kuşağı yalnızca farkındalık yaratan bir unsur olarak değerlendirmiştir. $\mathrm{Bu}$ farklılıklar dışında genelleme yapılacak olursa, hikâyeleştirilmiş içerik videoları hali hazırda 
satın alım gücü elinde olan her iki kuşak için de olumlu ve anlamlı olarak değerlendirilmişstir. Bunun nedeni ise her iki kuşak arasında beklenti ve davranış farklılıkarı olsa da günümüzde tüketicilerin tamamı deneyim ve değer çıktılarını önemsemektedir (Kotler vd., 2021:49). Hikayeleştirilmiş içerikler ise özellikle satın alım öncesinde tüketiciye ihtiyaç yaratma hem de satın alım sonrası tatmin açısından kullanılan en önemli araçlardan biri haline gelmiştir.

- Hikâyeleştirilmiş içerikler, geleneksel pazarlama araçlarına kıyasla daha fazla seyahat niyeti yaratır mi?

Evet, hem NAIDAS modeline göre geleneksel tanıtım videosu daha olumsuz değerlendirimiş hem de seyahat niyeti sorusu yöneltildiğinde tercih edilmemiştir. Yalnızca iki katılımcı geleneksel tanıtım videosunu olumlu değerlendirmiştir. Bunların biri $\mathrm{X}$ diğeri $\mathrm{Y}$ kuşağındandır. $\mathrm{Bu}$ da gösteriyor ki geleneksel videonun tercihi kuşağa bağlı bir tercih değildir. $\mathrm{Bu}$ katılımcıların yanıtları bu bağlamda incelendiğinde aslında kişilerin turist profillerinin farklılığı ortaya çıkmıştır. $\mathrm{Bu}$ katılımcılar bilgi odaklı turist profilinde olduğundan duygu temelli hikâyeleştirilmiş içerikler onlar için çok da etkili olmamaktadır. Elde edilen bu bulgu Artuner Özder'in (2020) çalışmasında elde ettiği bulgular ile örtüşmektedir. Çalışmaya göre farklı turist profillerinin (sosyo-demografik ve farklı güdülere sahip) beklerintilerinde de farklılıklar ortaya çıkmaktadır. Bir diğer çalışmaya göre de turist profilinin beklentileri etkilediğini ortaya koyan bu sonuç desteklenmektedir (Senbeto ve Hon, 2020).

Özetle, tanıtım içerikleri hazırlarken hedef kitlesini doğru belirlemek oldukça önemlidir. Yalnızca tek kuşağa hitap etmek istenmiyor ise mutlaka içerik pazarlaması bağlamında hikâyeleştirmeye yer verilmesi gerekmektedir.

Akademik öneriler bağlamında, hikâyeleştirmenin geniş çerçevede modelleştirilmesi ve özellikle pazarlama bağlamında nasıl kullanılması gerektiğine ilişkin derinlemesine araştırılması öneri olarak sunulabilir.

Sektörel bağlamda ise özellikle destinasyonların tanıtımında gerek var olan hikâyeleri kullanarak gerekse hikâyeleştirilmiş içerik ile kaliteli görselliği olan tanıtım videolarının kullanılması gerektiği önerilebilir. 


\section{KAYNAKÇA}

Akbayır, Z. (2016). Bana Bir Hikaye Anlat: Marka İletişiminde Hikayeleştirme ve İnternet. Karadeniz Teknik Üniversitesi İletişim Araştırmaları Dergisi, 6(2), 67-84.

Akgün, A. E., Keskin, H., Ayar, H., and Erdoğan, E. (2015). The Influence of Storytelling Approach In Travel Writings On Readers' Empathy And Travel Intentions. Procedia-Social And Behavioral Sciences, 207: 577-586.

Aktuğlu, I. K. (2006). Tüketicinin Bilgilendirilmesi Sürecinde Reklam Etiği. Küresel İletişim Dergisi, $2,1-20$.

Benli, T. ve Karaosmanoğlu, K. (2017). Bir Pazarlama Stratejisi Olarak İçerik Pazarlama. Mesleki Bilimler Dergisi, 6(1): 27-38.

Boje, D. M. (1991). The Storytelling Organization: A Study of Story Performance in an Office-Supply Firm. Administrative Science Quarterly, 106-126.

Cekada, T. (2012). Training A Multigenerational Workforce. USA: Professional Safety Rewiev.

Coupland, D. (1989). The Young and Restless Work Force Following the Baby Boom: Generation X. [Erişim Adresi: http://joeclark.org/dossiers/GenerationX.pdf] - [Erişim Tarihi: 20/02/2021].

Creswell, J. W. (2016). Araştırma Deseni: Nitel, Nicel ve Karma Yöntem Yaklaşımları. Ankara: Eğiten Kitap.

Denzin, N. K. and Lincoln, Y. S. (2005). Introduction: The Discipline and Practice of Qualitative Research. In N. K. Denzin and Y. S. Lincoln (Eds.). The Sage Handbook of Qualitative Research (3rd Ed., pp: 1-28). Thousand Oaks, CA: Sage

Diachuk, I., Britchenko, I. and Bezpartochnyi, M. (2019). Content Marketing Model for Leading Web Content Management. Advances in Social Science, Education and Humanities Research, 318: 119-126.

Fox, A. (2011). Mixing it Up. HRMagazine, May-2011, 22-27.

Goldstein, J. (2013). Content Marketing: The Smart Way to Grab Attention. ABA Bank Marketing, 45(10): 26-29.

Harad, C. C. (2013). Content Marketing Strategies to Educate and Entertain. Journal of Financial Planning, 26(3): 18-20.

Hüseyinoğlu, I. Ö (2017). Bütüncül Kanal (Omni-Channel) Stratejisinin İncelenmesi: Gida Perakendecisinden Bulgular. Dumlupınar Üniversitesi: Sosyal Bilimler Dergisi, Pazarlama Kongresi Özel Sayıs1: 119-133.

James B., Swanberg, J. E. and McKechnie, S. P. (2007). Generational Differences in Perceptions of Older Workers' Capabilities. The Center on Aging \& Work, Workplace Flexibilty at Boston College, Issue Brief 12 November, 1-10. 
Jefferson, S. and Tanton, S. (2015). Valuable Content Marketing: How to Make Quality Content Your Key to Success. Kogan Page Publishers.

Kaya B. (2020), Unutulmaz Turizm Deneyiminin Hikâye Anlatıcılı̆̆ına Etkisi. Batman Üniversitesi: Sosyal Bilimler Enstitüsü, Yüksek Lisans Tezi, Batman.

Kee, A. W. A. and Yazdanifard, R. (2015). The Review of Content Marketing as a New Trend in Marketing Practices. International Journal of Management, Accounting and Economics, 2(9): 1055-1064.

Kotler, P., Kartajaya, H. ve Setiawan I. (2010). Pazarlama 3.0. İstanbul: Optimist Yayınevi

Kotler, P., Kartajaya, H. ve Setiawan I. (2020). Pazarlama 4.0 Gelenekselden Dijitale Geçiş. İstanbul: Optimist Yayınevi.

Kotler, P., Kartajaya, H. ve Setiawan, I. (2021). Marketing 5.0: Technology for Humanity. New York: John Wiley \& Sons.

Krom, I. ve Guzel, E. (2006). Postmodern Branding Experience of Cultural Omnivores: Zorlu Center Case. Akademik Bakış Açısı Dergisi, Sayı: 55, 780-802.

Kurt, Ş. K. Enformasyonun Duygu Boyutu: Duygusal Bulaşıcılık Perspektifinden Sosyal Ağlarda Duygu Çalışmaları. İletişim Kuram ve Araştırma Dergisi, 2021(53), 109-136.

Mathews, R. ve Wacker, W. (2009). Senin Hikâyen Ne. Çeviren: Aytül Özer. İstanbul: MediaCat.

Mengi, Z. (2009). Z Kuşağı Geliyor. [Erişim Adresi: http://www.zeynepmengi.com/2012/06/z-kusagigeliyor/] - [Erişim Tarihi: 22.02.2021].

Mlodzik, K., \& DeMeuse, K. (2010). A Scholarly Investigation of Generational Workforce Differences: Debunking The Myths. Los Angeles, CA: Korn Ferry International.

Muskat, M., Muskat, B., Zehrer, A. and Johns, R. (2013). Generation Y: Evaluating Services Experiences Through Mobile Ethnography. Tourism Review, 68(3): 55-71.

Okan, E. Y. ve Yalman, N. (2013). Türkiye'de Tartışmalı Reklamlar: Kuşaklar Arası Karşılaştırma. Hacettepe Üniversitesi İktisadi ve İdari Bilimler Fakültesi Dergisi, 31(2): 135-152.

Özder, C. G. A. (2020). Çekim Faktörlerinin Turistik Varış Yeri Seçimindeki Rolü: Türkiye'deki Varış Yerlerinin Farklı Turist Profilleri Ve Beklentileri Karşısındaki Çekim Gücü Hakkında Bir Araştırma. Uluslararası Yönetim İktisat ve İşletme Dergisi, 16(3), 691-712.

Papadopoulos, A. and Shah, N. (2013). A Brand Journey to Engage Today's Customers: Prudential Financial. Journal of Brand Strategy, 2(2): 121-127.

Pazarlamasyon. (2017). X Kuşağı Hala Hedef Kitlenizde Olabilir. [Erişim Adresi: https://pazarlamasyon.com/x-kusagi-hala-hedef-kitlenizde-olabilir/] - [Erişim Tarihi: 20.02.2021].

Penpeçe, D. (2013). Dijital İçerik Pazarlaması. Adana: Karahan Kitabevi. 
Pera, R. (2017). Empowering The New Traveller: Storytelling As A Co-Creative Behaviour In Tourism. Current Issues In Tourism, 20(4): 331-338.

Pulizzi, J. (2012). The Rise of Storytelling as the New Marketing. Journal of Publishing Research Quarterly, 28(2): 116-123.

Rahim, K. and Clemens, B. (2012). Organizational Goals and Performance Measurement Criteria for Content Marketing. Journal of Communication and Computer, 9(8): 896-904.

Reilly, P. (2012). Understanding and Teaching Generation Y. English Teaching Forum, No: 1, Mexico, 1-11.

Ross, A. (1992). New Age Technoculture. New York: Verso.

Senbeto, D. L. ve Hon, A. H. (2020). The Impacts of Social and Economic Crises on Tourist Behaviour and Expenditure: An Evolutionary Approach. Current Issues in Tourism, 23(6), 740-755.

Toruntay, H. (2011). Takım Rolleri Çalışması: X ve Y Kuşağı Üzerinde Karşılaştırmalı Bir Araştırma. İstanbul Üniversitesi: Sosyal Bilimler Enstitüsü, Yayınlanmamış Yüksek Lisans Tezi, İstanbul.

Turgut, G. ve Kışla, T. (2015). Bilgisayar Destekli Hikâye Anlatımı Yöntemi: Alanyazın Araştırması. Turkish Online Journal of Qualitative Inquiry, 6(2): 97-121.

Türk Dil Kurumu. (2021). Hikâye Tanımı. [Erişim Adresi: https://sozluk.gov.tr/] - [Erişim Tarihi: 15.03.2021].

Türk, A. (2013). Y Kuşağı. İstanbul: Kafe Kültür Yayıncılık.

Uygur, S. M., Demirer, D. ve Hatırnaz, A. G. B. (2017). Turizm Pazarlamasında Alternatif Bir Araç Olarak Hikâyelerin Kullanımı. Akademik Sosyal Araştırmalar Dergisi, 5(42): 34-42

Yıldırım, A. ve Şimşek, H. (2008). Sosyal Bilimlerde Nitel Araştırma Yöntemleri. Ankara: Seçkin Yayınevi.

1. Çıkar Çatışması Beyanı: Yazarlar arasında çıkar çatışması yoktur.

2. Etik Kurul İzin Belgesi: Ankara Hacı Bayram Veli Üniversitesi Etik Komisyonundan 10.08.2021 tarih ve 07 sayılı toplantısı ile izin alınmıştır.

3. Araştırmacıların Katkı Oranı Beyanı: Yazarlar çalışmaya eşit oranda katkı sağlamıştır.

4. Destek ve Teşekkür Bilgisi: Katkılarından dolayı hakem ve editörlere teşekkür ederiz. 


\title{
Investigation of The Roles of Storyized and Traditional Video Promotions on Tourists Within Content Marketing: A Comparative Analysis of Generations X and Y
}

\section{Büşra KAYA}

Ankara Hacı Bayram Veli University, Institute of Graduate Programs, Ankara/Turkey

\section{Olcay GÜDEK}

Ankara Hacı Bayram Veli University, Institute of Graduate Programs, Ankara/Turkey

\author{
Azize HASSAN \\ Ankara Hacı Bayram Veli University, Faculty of Tourism, Ankara/Turkey \\ Extensive Summary
}

The narrative content, in which emotions are included, appeals to the postmodern consumer profile and supports the experience. Creating experience, making the consumer a producer, and interaction after postmodernism has become very important. For this reason, it is necessary to use enriched content when it comes to tourism. With storytelling, it is possible to create memorable experiences for tourists, involve them in the process and interact. For this reason, it is thought that storytelling to be used in the context of content marketing can change tourist behavior in the desired direction. This study, it is aimed to examine the role of the use of storytelling on tourists in the context of content marketing and to make a comparison between $\mathrm{X}$ and $\mathrm{Y}$ generations.

From the qualitative methods, the phenomenological pattern was adopted. During the research, ethical issues were taken into consideration in terms of validity and reliability. To ensure the validity of the research, the researchers carried out the analysis separately and finally decided on the final version together. In terms of reliability, the code meanings were not changed, the process was clearly stated and all interview documents were recorded. In this study, 21 potential tourists were interviewed. 11 participants were determined to be from the $\mathrm{X}$ generation and ten from the Y generation. A convenience sampling method was used.

Interview questions were prepared based on the NAIDAS model to examine the behavior and intentions of individuals. The questions were prepared in a semi-structured form. The questions used are as follows: 
1. How much did the video you watched create the need for you to travel? How would you define this need?

2. What kind of awareness did you experience about the destination after watching the video?

3. What was the most interesting point in the video you watched? Why did this pique your interest?

4. What is the situation or element in the video you watched that made you want to travel to that region? Why did this situation is made you want?

5. What motivates you to move in this video? Why did this move you?

6. At the end of the video you watched, what is the situation that you think will satisfy you most on this trip? Why do you think this situation will satisfy you?

The interviews were conducted face-to-face and using online methods due to the pandemic, and all interviews were recorded. The interviews were held in February and March 2021. In the study, two different types of promotional videos were watched in order to reveal the differences in the narrative content compared to other content. Videos are selected according to their content. Selected videos were watched sequentially by interviewers. First, the traditional promotional video was watched and questions were asked, then the second video was watched and questions were asked again. The reason for this is to pre-watch the narrative content and not manipulate the results to get the expected result. As a result of the interview were analyzed using content analysis.

The summary answers to the research questions in the light of the findings are compiled as follows:

How does the use of storytelling in the context of content marketing play on tourists compared to traditional marketing?

Traditional marketing has been negatively received by Generation $\mathrm{X}$ in terms of travel intention and many dimensions. The $\mathrm{Y}$ generation, on the other hand, prefers narrative content, although they do not evaluate it completely negatively. In this context, traditional, information-based old promotional videos no longer attract the attention of tourists. Moreover, narrative content marketing is seen as very effective in terms of experiencing and even experiencing it with loved ones.

Does the narrated content offer a different output on the $X$ and $Y$ generations? 
Although it offers the same outputs in general, it differs in some points. For example, while the $\mathrm{X}$ generation evaluates more emotionally (which is possible to reconcile with being the generation with the highest loyalty), the $\mathrm{Y}$ generation evaluates both cognitively and emotionally. Another difference is the video quality. Generation Y cares more about video quality. In addition, while the $\mathrm{X}$ generation cared more about sustainability and found it satisfactory, the $\mathrm{Y}$ generation considered it only as an awareness-raising element. Apart from these differences, if generalizations are made, storyized content videos are evaluated as positive and meaningful for both generations who already have the purchasing power.

Does storyized content generate more travel intent compared to traditional marketing tools?

Yes, both the traditional promotional video was evaluated more negatively compared to the NAIDAS model and it was not preferred when the question of travel intention was asked. Only two participants evaluated the traditional promotional video positively: one of them is from Generation $\mathrm{X}$ and the other is from Generation $\mathrm{Y}$. This shows that the choice of traditional video is not a generational choice. When the answers of these participants are examined in this context, the differences in the tourist profiles of the people have emerged. Since these participants are in the information-oriented tourist profile, emotional-based narrative contents are not very effective for them. 